K. O. Kalko ${ }^{1}$, S. M. Drogovoz ${ }^{1}$, S. Yu. Shtrigol ${ }^{1}$, A. V. Kononenko ${ }^{1}$, V. A. Ulanova ${ }^{1}$,

T. K. YUDKEVICH ${ }^{2}$

${ }^{1}$ National University of Pharmacy

${ }^{2}$ The Central Research Laboratory in National University of Pharmacy

\title{
CIRCADIAN CHARACTERISTICS OF THE GLUTARGIN INFLUENCE ON PROTEIN AND PURINE METABOLISM UNDER THE CONDITIONS OF CHRONODETERMINATED ACETAMINOPHEN HEPATITIS IN RATS
}

The aim of the work was to determine the circadian characteristics of the glutargin influence on protein and purine metabolism under the conditions of chronodeterminated acetaminophen hepatitis in rats. Typical phatology was simulating by acetaminophen administration (dose of $1000 \mathrm{mg} / \mathrm{kg}$ on the rat) in such periods and hours of the day and night as morning (9.00), afternoon (15.00), evening (21.00), and night (3.00). The glutargin was administration in medical-preventive regime, that is an hour before the acetaminophen administration and two hours after in dose of $135 \mathrm{mg} / \mathrm{kg}$ on the rat. As the results of this investigations was determined that glutargin administration against the background of the chronodeterminated acetaminophen hepatitis hadn't been characterized by changes of total protein and albumin contents, while the increasing level of carbamide was depending on circadian group of medicament (on 10-33\%) and decreasing level of uric acid was only in medicament of 9.00 am group (on $24 \%$ ). Obtained results should be taken into consideration in developing of glutargin chronoportrait.

Key words: liver; protein metabolism; glutargin

\section{INTRODUCTION}

Hepatobiliary system diseases are widely spread pathology that takes a significant place in morbidity and mortality of the population. A wide range of medical products are used for the pharmacological correction of this diseases. It is necessary to mark a group of specific medicines that have influence directly on hepatic - hepatoprotectors [10]. The pharmaceutical market of hepatoprotectors is quite diversified. It represented by medicines of herbal, chemical, synthetic and combined compositions $[3,5]$. A special role in the therapy among national drugs taking place the glutargin (L-glutamine and L-arginine mix ), this medicine based on amino acid. High therapeutic effectiveness of the glutargin had been confirming in practice during the treatment the massive outbreak of viral hepatitis A (Sukhodolsk, Lugansk region in 2003) [5, 10].

Rapid development of chronobiology, chronopathology and chronomedicine makes the requirement for knowledge of the peculiarity in drugs "chronoportraits". Drugs prescription will help us to optimize pharmacotherapy in view of circadian maximum of pharmacological and minimum of it's toxic effects, because it will allows us

(c) Group of authors, 2016 to use wellknown medicines with much higher effectiveness, reducing or completely neutralizing it's side effects.

The model of acute acetaminophen hepatitis is often used on preclinical stages during studying the perspective hepatoprotectors because of the liver injury' similar pathogenesis, that is observed in consequence of antibiotic, antifungal, antiepileptic and another medicines' pharmacotherapy with potential hepatotoxity $[2,5]$. A key part of the liver in protein and purine metabolism is well known, and determination of hepatoprotectors influence on protein metabolism (anabolic effect) is a component of overall analysis of drugs' hepatoprotective activity. Exploration the circadian dependence of glutargin influence in protein and purine metabolism under the conditions of acute acetaminophen hepatitis will allow us to consider the obtained information for characterizing drug' "chronoportrait".

Aforementioned confirms an actuality in carrying the chronopharmacologiacal investigations of the glutargin hepatoprotector with the aim of identifying it's chronopharmacologiacal specificity.

\section{MATERIALS AND METHODS}

Circadian dependence of the glutargin influence on protein and purine metabolism have been studying during spring season (in March 2015) by chronodeterminated 
Table 1

THE GLUTARGIN INFLUENCE ON CIRCADIAN RHYTHMS OF PROTEIN AND PURINE METABOLISM (n = 96)

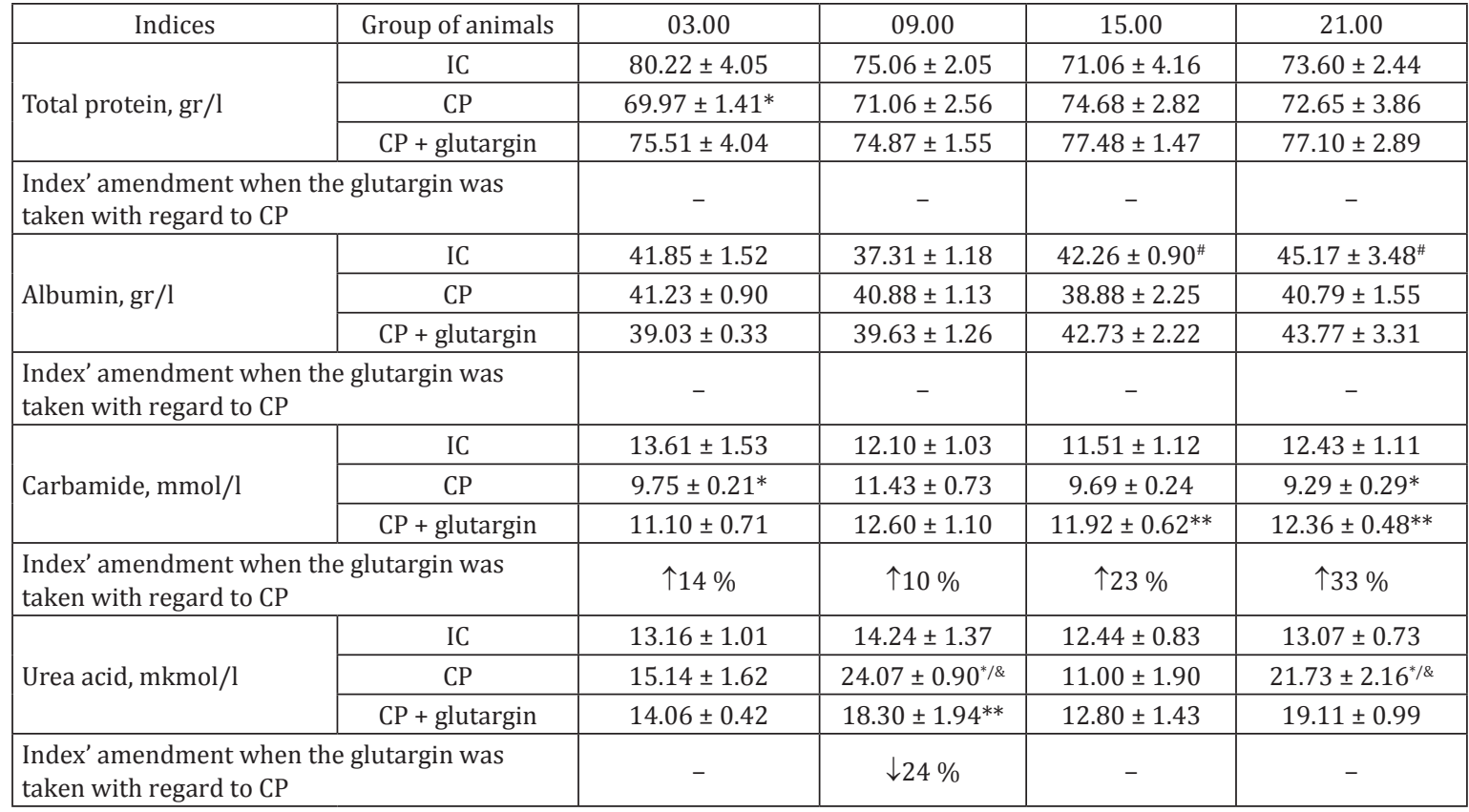

Note: $\mathrm{n}$ - the number of animals in experience; ${ }^{*}$ - index deviation authentically and significantly differ from index of intact animals $(\mathrm{p}<0.05)$; ** - index deviation authentically and significantly differ from index of animals group with hepatitis $(\mathrm{p}<0.05)$; \# - index deviation authentically and significantly differ from minimal index in group of intact animals $(\mathrm{p}<0.05) ; \&$ - index deviation authentically and significantly differ from minimal index in group of animals with hepatitis $(\mathrm{p}<0.05)$.

acetaminophen liver injury' model. Had been investigated 96 rats (females) by 8 animals from each circadian group of intact control, the model pathology and the glutargin administrated rats. Modelling of acute acetaminophen hepatitis had been reproduced by single acetaminophen administration $(1000 \mathrm{mg} / \mathrm{kg}$ ) on following periods and hours of the day: morning (9.00), afternoon (15.00), evening (21.00) and night (3.00).The glutargin had been administration to rats in medical-preventive regime (an hour before acetaminophen administration and two hours after) in dose of $135 \mathrm{mg} / \mathrm{kg}$ [7]. Decapitation of animals with blood sampling for getting blood serum had been realized after acetaminophen administration through 24 hours. Contents of total protein, albumin, carbamide and uric acid had been identifying in blood serum with the help of stan dart test-sets that were manufactured by "Filisit-diagnostic" and "SpaynLab" [4].

Experiences had been realizing under IR - lamp with the purpose of leveling the influence of optical factor on melatonin synthesis in the evening and night [9]. Obtained results had been processing with the help of Cosinor-Analisis 2.4 for Excel 2000/XP program, statistical programs package "Statistica 8,0" and nonparametric MannWhitney U-test. By comparing statistical indices was accepted the significance level $\mathrm{p}<0.05$ [6].

With the help of Cosinor-Analisis 2.4 for Excel 2000/XP program had been calculating the mezor (an average value of studied index during the day) and amplitude (maximal aberration both sides from mezor). During the chronograms analysis had been determined an acrophaze (an hour of the day when it marked the maximal value of studied index) and the batiphaze (an hour of the day when it marked the minimal value of studied index) [11].

\section{RESULTS AND DISCUSSION}

The glutargin injections against the background of the chronodeterminated acute acetaminophen hepatitis hadn't been characterized by distinctive changes of total protein contents. It is proved by mesor - rhythm value of this index in groups of the glutargin $(76.24 \pm 1.10 \mathrm{gr} / \mathrm{l})$ that was on the one level in intact rats $(74.98 \pm 2.07 \mathrm{gr} / \mathrm{l})$ and in animals with control pathology $(72.09 \pm 1.82 \mathrm{gr} / \mathrm{l})$. While index's rhythm amplitude was less in 1.4 times in glutargin groups of animals with hepatitis and was less in 1.7 times by comparison with intact rats (Tab. 2). When glutargin was taking an acrophaze of the total protein contents was inphased in animals with hepatitis (but not in intact animals) and was observed on $15.00 \mathrm{pm}$ while the batiphaze was observed on 9.00 am (synphasicity with another research groups hadn't been registered) (Tab. 1).

An albumin contents (the total protein fraction) almost hadn't been changed in comparison from the rats with hepatitis when the glutargin was taken (Tab. 1), it is confirming by mezor of this index: $41.29 \pm 1.22 \mathrm{gr} / \mathrm{l}$ in the glutargin group and $40.44 \pm 0.25 \mathrm{gr} / \mathrm{l}$ in animals with hepatitis. Rhythm amplitude growth of an albumin contents had been observed in animals who were medicated by glutargin in 2.4 times comparatively to rats from control pathology (Tab. 1). An acrophaze of this index in glutargin group is inphased those in intact rats and is 
THE GLUTARGIN INFLUENCE ON CIRCADIAN INDICES OF PROTEIN AND PURINE METABOLISM BY COSINOR-ANALISIS 2.4 FOR EXCEL 2000/XP PROGRAMME

\begin{tabular}{|c|c|c|c|c|c|}
\hline \multirow{2}{*}{ Chronoindex } & Group of animals & Total protein, gr/l & Albumin, gr/l & $\begin{array}{c}\text { Carbami de, } \\
\mathrm{mmol} / \mathrm{l}\end{array}$ & \begin{tabular}{c} 
Urea acid, mkmol/l \\
\multirow{3}{*}{ Mesor }
\end{tabular} \\
\cline { 2 - 6 } & IC & $74.98 \pm 2.07$ & $41.65 \pm 1.22$ & $12.41 \pm 0.55$ & $13.23 \pm 0.62$ \\
\cline { 2 - 6 } & CP & $72.09 \pm 1.82$ & $40.44 \pm 0.25$ & $10.04 \pm 0.25$ & $17.98 \pm 0.84 *$ \\
\hline \multirow{3}{*}{ Amplitude } & IC & $76.24 \pm 1.10$ & $41.29 \pm 1.22$ & $11.99 \pm 0.45$ & $16.07 \pm 0.84$ \\
\cline { 2 - 7 } & CP & $2.48 \pm 1.14$ & $1.18 \pm 0.88$ & $1.07 \pm 0.30$ & $2.38 \pm 0.96$ \\
\cline { 2 - 7 } & CP + glutargin & $1.49 \pm 0.86$ & $2.77 \pm 1.49$ & $0.43 \pm 0.30$ & $0.75 \pm 0.54$ \\
\hline
\end{tabular}

Note: $*$ - index deviation authentically and significantly differ from index of intact animals $(\mathrm{p}<0.05)$.

observing on 21.00 pm while the batiphaze is observing on 3.00 am (synphasicity with another research groups hadn't been registered) (Tab. 1).

The glutargin had been stimulating the growth of carbamide contents on 10-33\% according to circadianity of the medicine group (Tab. 1). That's why rhythm mezor of this index in the glutargin groups had been rising from $10.04 \pm 0.25$ (rats with hepatitis) to $11.99 \pm 0.45 \mathrm{mmol} / \mathrm{l}$ when drug was taken, in this case amplitude had been reducing in 2.5 times comparatively to animals with hepatitis (Tab. 2). An acrophaze of the carbamide contents in glutargin groups $(9.00 \mathrm{am})$ is inphased to rats with pathology and was observed on $09.00 \mathrm{am}$, while the batiphaze was observed on 03.00 am (synphasicity with another research groups hadn't been registered) (Tab. 1).

It had been registered an authentic reduction (on $24 \%$ ) of urea acid contents in group of medicine on $9.00 \mathrm{am}$ comparatively to animals with control pathology when the glutargin was taken, when it wasn't practically significant changes of this index' value in another circadian groups of medicine (Tab. 1). That's why the rhythm mezor of urea acid contents reduction was not expressive from $17.98 \pm 0.84$ (control animals) till $16.07 \pm 0.84 \mathrm{mkmol} / \mathrm{l}$ when the glutargin was taken. The level of urea acid rhythm amplitude contents had been decreasing distinctively (in 3.2 times), regarding to animals with hepatitis, and practically obtained the value of rats from intact control, when the glutargin was taken (Tab. 2). An urea acid acrophaze and the betaphase are inphased to intact and control animals in the glutargin groups and had been registered on 09.00 am and $15.00 \mathrm{pm}$ accordingly (Tab. 1).

Thus, medical-preventive regime of the glutargin administration in the backgroung of the chronodeterminated acetaminophen hepatitis had a tendency to leveling up the contents of total protein in groups of medicine on 03.00 am and $09.00 \mathrm{am}$, to increasing the level of carbamide on $10-33 \%$ according to circadianity of the medicine group and to decreasing the level of urea acid in group of medicine on $09.00 \mathrm{am}$. In abovementioned conditions the glutargin taken hadn't stimulated the contents changes of an albumin in regard to intact animals and rats with hepatitis.
The glutargin ability to increase the contents of blood carbamide in pathological conditions first of all connected with the medicine's components: arginine and glutamic acid. In particular, arginine neutralizes ammonium and transforms it into non-toxic compound the carbamide, in this way it improves the tendency of detoxifying processes in liver, and glutamine neutralizes ammonium taking part in Krebs cyrcle [5]. The glutargin ability to increase the carbamide contents during the day is characterized by circadian dependence and is determined by circadian course of the metabolic processes in hepatocytes [11].

The most distinctive reduction of an urea acid contents under the glutargin influence had been observed in medicine group on 09.00 am and probably was determined by circadian aspect of an antioxidant and membrane-stabilizative characteristics of the glutargin [11]. This fact prevents the intracellular components going out into blood serum and saving activity of an urease enzyme (when medicine taking in the morning). This ferment takes part in urea acid metabolism till the final product an allantoin in hepatocytes [1]. All abovementioned results should be considered in the overall development of the glutargin chronoportrait.

\section{CONCLUSIONS}

1. In conditions of the chronodeterminated acetaminophen hepatitis glutargin taking hadn't been characterized by changing the contents of total protein and albumin in all circadian groups of medicines.

2. The glutargin taking against the background of the chronodeterminated hepatitis had been characterized by increasing level of carbamide contents in all circadian groups of medicine with the most significant and authentic growth of this index in the evening and night (23-33\%).

3. Decreasing level of urea acid (on $24 \%$ ) when the glutargin was injected against the background of acetaminophen pathology had been observed only in the morning without changes of the index value during another periods of the day. 


\section{REFERENCES}

1. Біохімія: [підруч.] / За заг. ред. проф. А. Л. Загайко, проф. К. В. Александрової. - Х.: Вид-во «Форт», 2014. - 728 c.

2. Доклінічні дослідження лікарських засобів: [метод. рекоменд.] / За ред. чл.-кор. НАМН України О. В. Стефанова. - К.: Авіценна, 2001. - 528 с.

3. Дроговоз С. М. Фармакология в помощь студенту, провизору и врачу: [учеб.-справ.] / С. М. Дроговоз, С. Ю. Штрыголь, Е. Г. Щекина. - Х.: Титул, 2013. - 900 c.

4. Камышников В. С. Справочник по клинико-биохимической лабораторной диагностике: в 2-х т. / В. С. Камышников. - Мн: Беларусь, 2000. - Т. 1. - 495 с.

5. Матвеев А. В. Гепатопротекторы. Анализ международных исследований по препаратам группы лекарств для печени. - Симферополь: ИТ «Ариал», 2013. - 384 с.

6. Реброва О. Ю. Статистический анализ медицинских данных. Применение пакета прикладных программ STATISTICA. - 3-е изд. - М.: МедиаСфера, 2006. - 312 c.
7. Рыболовлев Ю. Р. Дозирование веществ для млекопитающих по константе биологической активности / Ю. Р. Рыболовлев, Д. С. Рыболовлев // Докл. AH CCСР. - 1979. - Т. 247, № 6. - С. 1513-1516.

8. Руководство по проведению доклинических исследований лекарственных средств / Под ред. докт. мед. наук А. Н. Миронова. - М.: Гриф и К, 2012. - Ч. 1. - 944 c.

9. Семененко С. Б. Особливості структури хроноритмів екскреторної функції нирок за умов гіперфункції шишкоподібної залози // Буковинський мед. вісник. - 2014. - Т. 18, № 2 (70). - С. 99-101.

10. Соломенник Е. В. Влияние препарата глутаргин на клинико-биохимические показатели у больных острым вирусным гепатитом А / А. О. Соломенник, Е. В. Юрко, Е. И. Могиленець, К. И. Никитина // Актуальні питання фарм. і мед. науки та практики. - 2010. - № 4. - С. 107-109.

11. Хронофармакология наглядно (Хронофармакология в таблицах и рисунках): [справ.-учеб. пособие] / Под ред. С. М. Дроговоз. - Х.: Титул, 2014. -128 c.

\section{УДК 616.36:57.034:577.12}

К. О. Калько, С. М. Дроговоз, С. Ю. Штриголь, А. В. Кононенко, В. А. Уланова, Т. К. Юдкевич ЦИРКАДІАННІ ОСОБЛИВОСТІ ВПЛИВУ ГЛУТАРГІНУ НА БІЛКОВИЙ ТА ПУРИНОВИЙ ОБМІНИ В УМОВАХ ХРОНОДЕТЕРМІНОВАНОГО ПАРАЦЕТАМОЛОВОГО ГЕПАТИТУ У ЩУРІВ

Метою даної роботи було встановлення циркадіанних особливостей впливу глутаргіну на білковий та пуриновий обміни в умовах хронодетермінованого парацетамолового гепатиту у щурів. Модельну патологію відтворювали введенням парацетамолу (у дозі 1000 мг/кг щура) в такі періоди та години доби: ранковий (09.00), денний (15.00), вечірній (21.00) та нічний (03.00). Глутаргін вводили в лікувально-профілактичному режимі, тобто за 1 год до введення парацетамолу та 2 год після цього в дозі 135 мг/кг щура. В результаті проведених досліджень встановлено, що введення глутаргіну на тлі хронодетермінованого парацетамолового гепатиту не характеризувалося змінами вмісту загального білка та альбуміну, тоді як збільшення вмісту сечовини залежало від циркадіанності групи препарату (на 10-33 \%), а зменшення вмісту сечової кислоти спостерігалося лише в групі препарату о 09.00 (на 24 \%). Отримані результати слід враховувати при розробці хронопортрету глутаргіну.

Ключові слова: печінка; білковий обмін; глутаргін

УДК 616.36:57.034:577.12

Е. А. Калько, С. М. Дроговоз, С. Ю. Штрыголь, А. В. Кононенко, В. А. Уланова, Т. К. Юдкевич ЦИРКАДИАННЫЕ ОСОБЕННОСТИ ВЛИЯНИЯ ГЛУТАРГИНА НА БЕЛКОВЫЙ И ПУРИНОВЫЙ ОБМЕНЫ В УСЛОВИЯХ ХРОНОДЕТЕРМИНИРОВАННОГО ПАРАЦЕТАМОЛОВОГО ГЕПАТИТА У КРЫС

Целью данной работы является определение циркадианных особенностей влияния глутаргина на белковый и пуриновый обмены в условиях хронодетерминированного парацетамолового гепатита у крыс. Модельную патологию воспроизводили введением парацетамола (доза 1000 мг/кг для крысы) в следующие периоды и часы суток: утренний (09.00), дневной (15.00), вечерний (21.00) и ночной (03.00). Глутаргин вводили в лечебно-профилактическом режиме, то есть за 1 час до введения парацетамола и через 2 часа после в дозе 135 мг/кг для крысы. В результате проведенных исследований установлено, что введение глутаргина на фоне хронодетерминированного парацетамолового гепатита не характеризировалось изменениями содержания общего белка и альбумина, тогда как увеличение содержания мочевины зависело от циркадианности группы препарата (на 10-13 \%), а уменьшение содержания мочевой кислоты наблюдалось только в группе препарата в 09.00 (на 24 \%). Полученные результаты следует учитывать при разработке хронопортрета глутаргина.

ключевые слова: печень; белковый обмен; глутаргин

Адреса для листування:

Надійшла до редакції 10.06.2016 p.

61002, м. Харків, вул. Куликівська, 12.

Національний фармацевтичний університет 